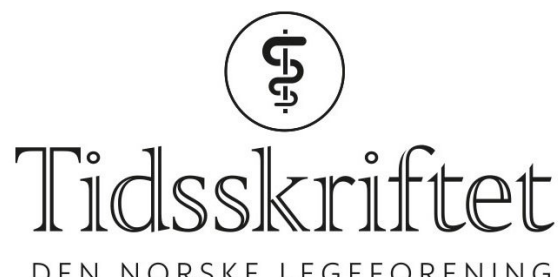

DEN NORSKE LEGEFORENING

\title{
Torunn Fiskerstrand
}

MINNEORD

ANNE KARIN BRIGTSEN

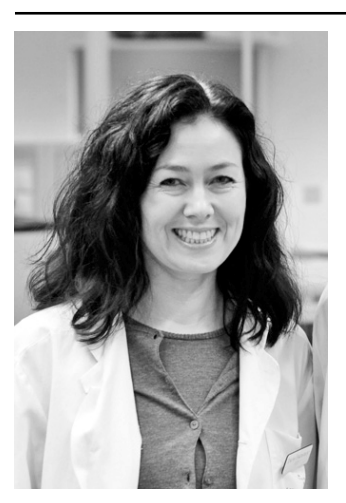

Torunn Fiskerstrand døydde av kreft den første dagen i det nye året, berre 53 år gamal. Me møttest tidleg på medisinstudiet i Bergen og vart snart gode vener. Torunn var glad i musikk, litteratur og fjellet. Me gjekk toppturar i Sunnmørsalpane, feira 17. mai på Hardangerjøkulen og var bunadskledde guidar under Festspela i Bergen.

Torunn var nysgjerrig og grundig. Ho ville finne ut kvifor, var ikkje nøgd med enkle svar. Det var difor ikkje overraskande at ho mot slutten av studiet starta å forske, og i 1999 vart ho dr.philos. Kort tid etter byrja ho ved Avdeling for medisinsk genetikk ved Haukeland universitetssjukehus. I tillegg til å vere ein svært god lege, var ho ein eminent forskar. Den viktigaste oppdaginga var genetisk kartlegging av ein arveleg diarésjukdom, eit arbeid som vart publisert i verdas fremste medisinske tidsskrift, New England Journal of Medicine. Torunn var i mange år medlem av Bioteknologirådet og leiar av Norsk forening for medisinsk genetikk. Hennar siste, store arbeid var å utvikle og ferdigstille Genetikkportalen, ei nettside som gjev informasjon om genetiske sjukdomar og om kva gentestar som blir utført i Norge. Dette er blitt eit viktig verktøy både for genetikarar og klinikarar.

Torunn gjorde Bergen til sin by, og det var alltid kjekt å kome på besøk. Ho var eit menneske det var godt å vere saman med. Med stor hjartevarme diska ho opp med nydeleg mat og utsøkt vin, og me kunne snakke saman om små og store ting i livet langt inn i dei små timar. Torunn var både sterk og sårbar. Det var derfor ikkje tilfeldig at å danse tango vart ein stor lidenskap. Gjennom tangodansen kom denne dualismen fram. Gjennom tangoen trefte ho òg sin kjæraste, Peter.

Torunn kunne som få andre stråle av livsglede, og det er ufatteleg at ho ikkje lenger lever. 
Publisert: 9. september 2019. Tidsskr Nor Legeforen. DOI:10.4045/tidsskr.19.0471 (C) Tidsskrift for Den norske legeforening 2020. Lastet ned fra tidsskriftet.no 